\title{
The Dynamic Role of Pollock (Pollachius virens) as a Predator in the Northeast US Continental Shelf Ecosystem: a Multi-decadal Perspective
}

\author{
M. C. Tyrrell, J. S. Link, H. Moustahfid, and B. E. Smith \\ National Marine Fisheries Service, Northeast Fisheries Science Center, \\ Woods Hole Laboratory, 166 Water St., Woods Hole, MA 02543, USA \\ Corresponding author: Megan.Tyrrell@noaa.gov
}

Tyrrell, M. C., J. S. Link, H. Moustahfid, and B. E. Smith. 2007. The dynamic role of pollock (Pollachius virens) as a predator in the Northeast US continental shelf ecosystem: a multi-decadal perspective. J. Northw. Atl. Fish. Sci., 38: 53-65. doi:10.2960/J.v38.m605

\begin{abstract}
The Northeast US continental shelf ecosystem has been subject to heavy fishing pressure and other anthropogenic influences that have directly and, through food web interactions, indirectly affected the abundance of fish and invertebrates. The role of pollock (Pollachius virens) as one of the key groundfish predators in this ecosystem has changed accordingly over the last three decades. We utilized a thirty-three year food habits database with over 5500 pollock stomachs to examine relative removal of commercially valuable fish and invertebrate prey by pollock. Pollock diet composition has substantially shifted through time and appears closely tied to the relative availability of prey. Pollock diet shifted from euphausiids, squid and sandlance early in the time series to decapod shrimp, herrings and hakes in recent years. Both small and large size classes of pollock have shown an increased proportion of fish in the diet through time. Pollock has, at times, exerted notable predatory removals on squid, and to a lesser extent, on herring and mackerel. The implications of pollock consumption on prey population dynamics is discussed in light of the recent trend of its increasing biomass.
\end{abstract}

Key words: consumption, diet, Georges Bank, groundfish, Gulf of Maine, prey removals, saithe

(C) US Government, 2007

\section{Introduction}

The Northeast US continental shelf ecosystem has undergone substantial changes in community structure from the 1960s to the present. Much of these shifts have been driven by sequential overfishing of various fish stocks (Fogarty and Murawski, 1998; Garrison and Link, 2000a). The major change has been a biomass shift from demersal groundfish species to elasmobranchs (Fogarty and Murawski, 1998), followed by a notable increase in pelagic species (herring, mackerel and squid) in recent years (Overholtz et al., 1999). Similar to other principal groundfish species, pollock (Pollachius virens) abundance has strongly fluctuated in the past several decades (Mayo et al., 1989). Although pollock constitute a relatively small fraction of the principle groundfish biomass in the Northeast US continental shelf ecosystem (Mayo et al., 2005b), pollock population fluctuations may have substantial effects on both its competitors and prey.

Pollock diet in the northwestern Atlantic has traditionally been characterized as primarily composed of pelagic species, particularly euphausiids (Marak, 1960; Dexter, 1969; Cargnelli et al., 1999; Link and Almeida, 2000; Carruthers et al., 2005). However, a recent investigation in the Scotian Shelf and Bay of Fundy revealed that the occurrence of euphausiids in pollock stomachs had greatly decreased as compared to samples obtained three decades earlier (Carruthers et al., 2005). If pollock diet has shifted among major prey groups, it could affect energy flow through the groundfish community of the northwest Atlantic. We investigated several aspects of pollock trophic ecology to understand how fluctuations in the Northeast US continental shelf ecosystem 
may have affected its role as a predator. Our food habits data span more than three decades, providing a unique long term perspective on how pollock diet composition, consumption rates and removals of particular prey have changed as the larger ecosystem has been affected by fishing and other anthropogenic influences.

Predation may affect stock sizes of commercially valuable species, such as Atlantic herring (Overholtz and Link, 2007), walleye pollock (Theragra chalcogramma) (Hollowed et al., 2000), or other species highly susceptible to natural predators and fishing pressure. Variability in natural mortality due to predation is becoming an increasingly important factor to incorporate into assessments of species that are subject to high mortality from humans as well as other marine predators (e.g. Hollowed et al., 2000; Tsou and Collie, 2001a; Overholtz and Link, 2007). We examined temporal variation in the type and amount of prey consumed by pollock to examine how major diet shifts may relate to changes in prey availability. These types of efforts to quantify predatory removals are essential for effectively modeling population dynamics of strongly interacting species and for understanding larger ecosystem functions.

\section{Methods}

\section{Biomass and landings data}

The Northeast Fisheries Science Center (NEFSC) bottom trawl survey is designed to collect fishery independent biomass and abundance data using standardized research vessel surveys with a stratified random survey design. Fig. 1 shows the geographic scope of the bottom trawl survey which spans from Cape Hatteras to the Scotian Shelf. This is also the area inhabited by pollock. The autumn survey was initiated in 1963 and spring surveys have been conducted since 1968; summer and winter trawl surveys are also periodically conducted. Details about the bottom trawl survey design and protocols are provided by Azarovitz (1981) and NEFC (1988). We used the trawl survey database for annual abundance and biomass estimates (1963-2005) calculated using a minimum swept area for the entire trawl survey region. Annual averages were used to compare temporal changes in pollock biomass with its percentage of the total finfish community biomass for the same time period.

Pollock landings data for 1964-2005 were obtained from the US National Marine Fisheries Service (NMFS), Northeast Region commercial fishery species database. Annual averages were used to present pollock landings trends for this time period.

\section{Food habits data}

The NEFSC has sampled fish stomachs obtained from the bottom trawl survey since 1973. From 1973-1981, pollock stomachs were individually preserved in $10 \%$ buffered formalin for identification of prey items in the laboratory. Data recorded for each stomach were: total stomach weight $(0.01 \mathrm{~g})$, prey weight $(0.01 \mathrm{~g})$ and number, lengths of fish prey $(\mathrm{mm})$ and percent composition (based on weight) of prey identified to the lowest taxon feasible. Any stomach showing signs of regurgitation (e.g. wholly or partially inverted, flaccid) was discarded. Starting in 1981, stomachs of pollock were examined at sea. The at-sea sampling was similar to the laboratory based data collection with the exception that prey weights were replaced with volumetric estimation (cc). Volumes are converted to weight (g) using an empirically derived ratio of 1.1:1 (Link and Almeida, 2000: $\left.N=10806, r^{2}=0.906, p<0.0001\right)$. A detailed description and history of the food habits sampling protocols is given in Link and Almeida (2000).

Data from a total of 5569 pollock stomachs were used in this study. Pollock were split into small and large size classes ( $\leq 50$ and $>50 \mathrm{~cm}$ length respectively) to examine abundance, diet compositions and consumption (described below). To insure adequate sample sizes for a particular time period, diet compositions were calculated in five year blocks subsequent to 1975. Table 1 shows sample sizes for each year block and size class combination.

\section{Consumption calculations}

Gastric evacuation rates were calculated using the method of Eggers (1977) and Elliott and Persson (1978). This method has been used extensively in this region as a basis for calculating consumption (e.g. Overholtz et al., 1999, 2000, 2008; Tsou and Collie, 2001a, 2001b; Link

TABLE 1. Number of pollock stomachs for each size class and year block combination for diet composition analysis.

\begin{tabular}{ccc}
\hline \hline Year block & Small $(\leq 50 \mathrm{~cm})$ & Large $(>50 \mathrm{~cm})$ \\
\hline $1973-1975$ & 122 & 275 \\
$1976-1980$ & 79 & 181 \\
$1981-1985$ & 371 & 487 \\
$1986-1990$ & 463 & 444 \\
$1991-1995$ & 838 & 401 \\
$1996-2000$ & 760 & 361 \\
$2001-2005$ & 423 & 364 \\
\hline
\end{tabular}


and Garrison, 2002a; Link et al., 2002, 2006; NEFSC, 2007; Overholtz and Link, 2007). Daily per capita consumption estimates $(\mathrm{g})$ for small and large pollock were based on stomach evacuation rates and average stomach contents of each size class:

$$
C=24 E \bar{S}^{\gamma}
$$

where 24 is the number of hours in a day, $\bar{S}$ is the annual mean stomach contents weight $(\mathrm{g}), \gamma$ is a derived param- eter which we set equal to 1 (Gerking, 1994) and $E$ is the evacuation rate. The evacuation rate is calculated as:

$$
E=\alpha e^{\beta T}
$$

where $T$ is the average temperature and $\alpha$ and $\beta$ were set equal to 0.04 and 0.11 respectively. These $\alpha$ and $\beta$ values are considered relatively conservative for teleost fish (Durbin et al., 1983). Annual mean bottom temperatures for the whole Northeast US shelf were calculated using

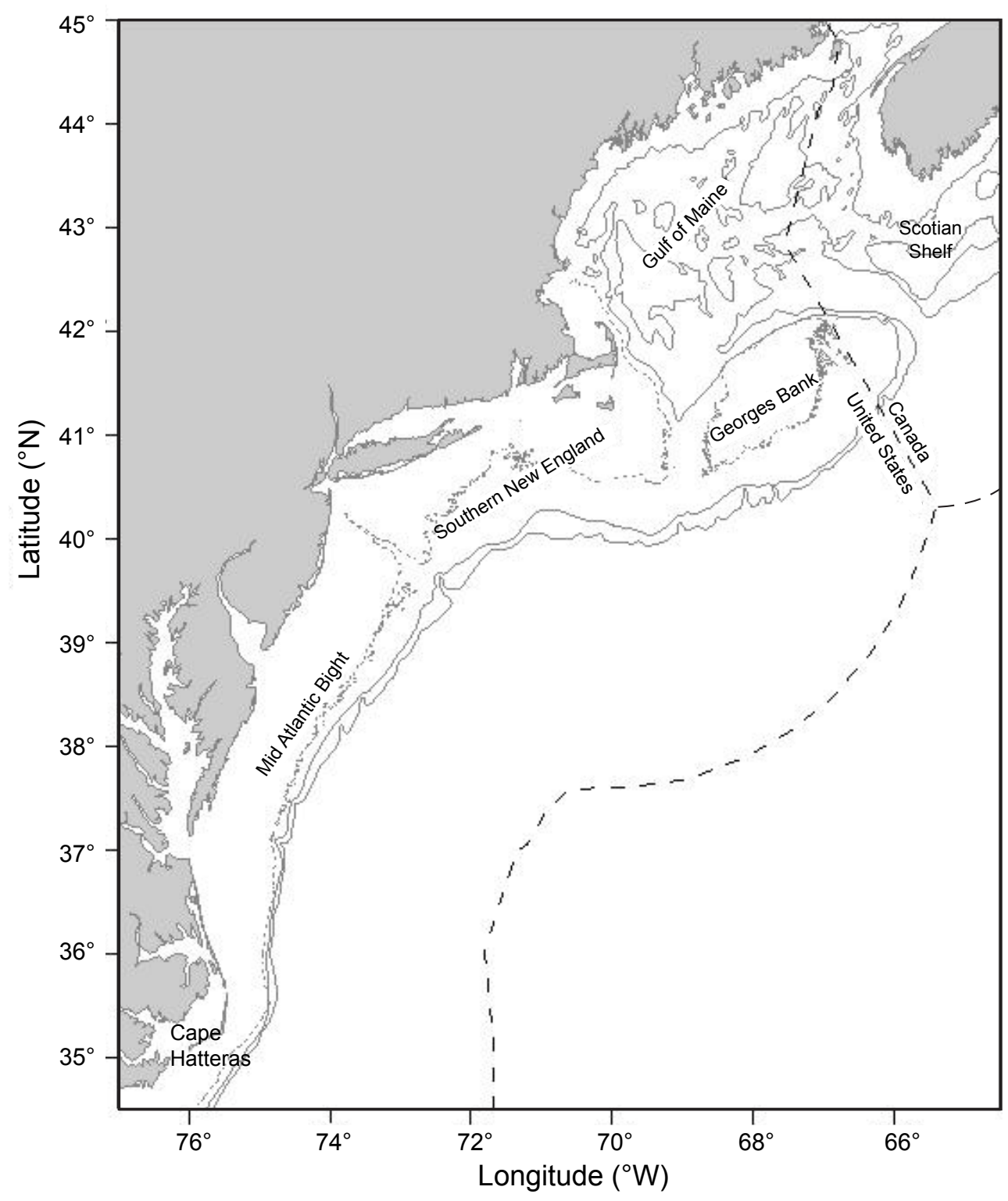

Fig. 1. Map of the Northeast US continental shelf ecosystem which is inhabited by pollock. Depth contour lines represents the 50,100 and $200 \mathrm{~m}$ isobaths. The dashed line represent the EEZ boundary. 
Mountain et al.'s (2004) method to interpolate temperatures between trawl stations. Daily rations, or the amount of food consumed per 24 hour period as a fraction of body weight, were calculated starting in 1992, when individual fish weights were recorded on the bottom trawl survey. Daily per capita consumption was multiplied by 365 to get an estimate of annual per capita consumption, $C^{\prime}$.

A population estimate of total annual consumptive removal, $C_{t o t}$, was calculated by adding the product of the annual per capita consumption and the swept area estimate of annual abundance for each pollock size class (small, $N_{S}$, and large, $N_{L}$ ):

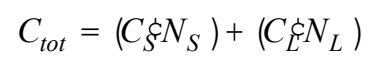

\section{Prey removals}

The total annual removal by pollock for each of its nine major prey categories was determined by multiplying the percent (by weight) of a prey group in the diet by pollock total annual removal. To place pollock consumption into a broader ecosystem context, the fraction of pollock consumptive removals averaged over the whole time series relative to the total energy flows in the system was calculated (Link et al., 2006). For some species that support commercial fisheries, we compared the amount of biomass consumed by pollock relative to the total biomass for the species. We referenced stock assessments wherever possible (e.g. herring (Overholtz et al., 2004; Overholtz, MS 2006a), mackerel (Overholtz, MS 2006b) and longfin squid (Loligo pealii) (NEFSC, 2002)) and the autumn bottom trawl survey abundance for northern shortfin squid (Illex illecebrosus), because it lacks a current assessment.

\section{Results}

\section{Biomass and Landings trends}

The annual average of the bottom trawl survey shows that total pollock biomass was very high in the late 1970s to the mid 1980s (Fig. 2). There have been relatively minor fluctuations in the biomass of small pollock over time. In contrast, the temporal fluctuations exhibited by the large size class have dominated the results for total pollock biomass. The entire stock underwent sharp declines from the late 1980s to the mid 1990s, and has increased slightly since 2000 . The biomass index of all pollock in recent years has been approximately $25 \%$ of the peak levels recorded in late 1970s. Pollock contribution to the total finfish biomass closely mirrored its population level fluctuations. Over the past four decades, pollock has, on average, constituted approximately 3\% of the total finfish biomass in this ecosystem.

The annual average of pollock landings from Georges Bank and the Gulf of Maine shows a peak in the mid 1980s of 24000 metric tons (Fig. 3). Landings for the past several years have been consistently low and at levels comparable to those of the 1970s, which was about $25 \%$ of the peak landings period of the mid 1980s. The timing of highest landings of pollock lagged behind its peak abundance in the bottom trawl survey by several years.

\section{Diet}

There have been considerable temporal shifts in the major components of pollock diet over the past three decades. In some cases for small pollock, the size of the confidence interval was correlated with the importance of a prey category in the diet (Figs. 4a and 4b). In the late 1970 s to early 1980 s, when pollock biomass was at

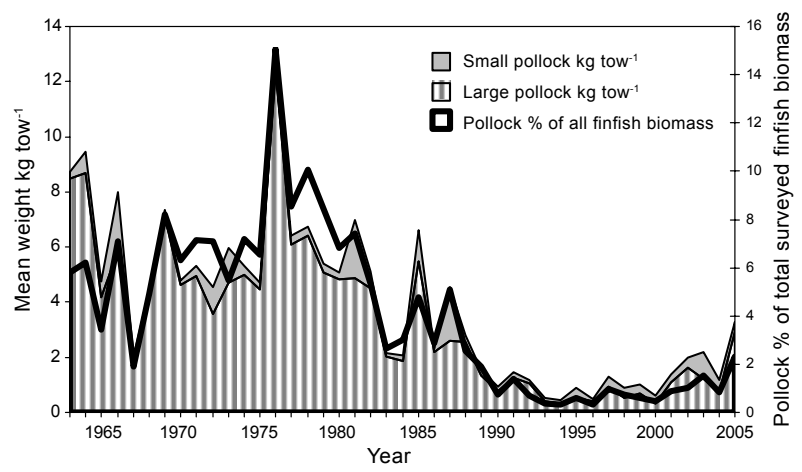

Fig. 2. Annual average pollock biomass $\left(\mathrm{kg} \mathrm{tow}^{-1}\right)$ for small, large and both size classes combined, and percent of total finfish biomass obtained in NEFSC's bottom trawl research surveys from 1963-2005.

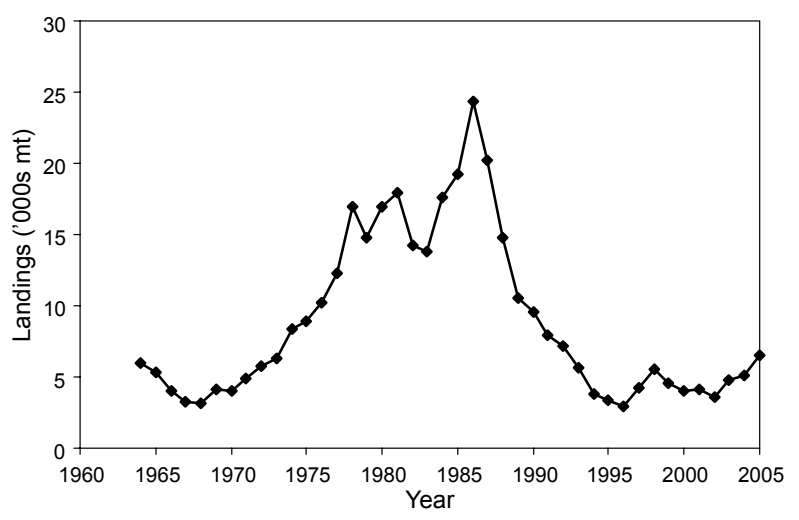

Fig. 3. Annual commercial landings of pollock from Georges Bank and the Gulf of Maine from 1964-2005. 


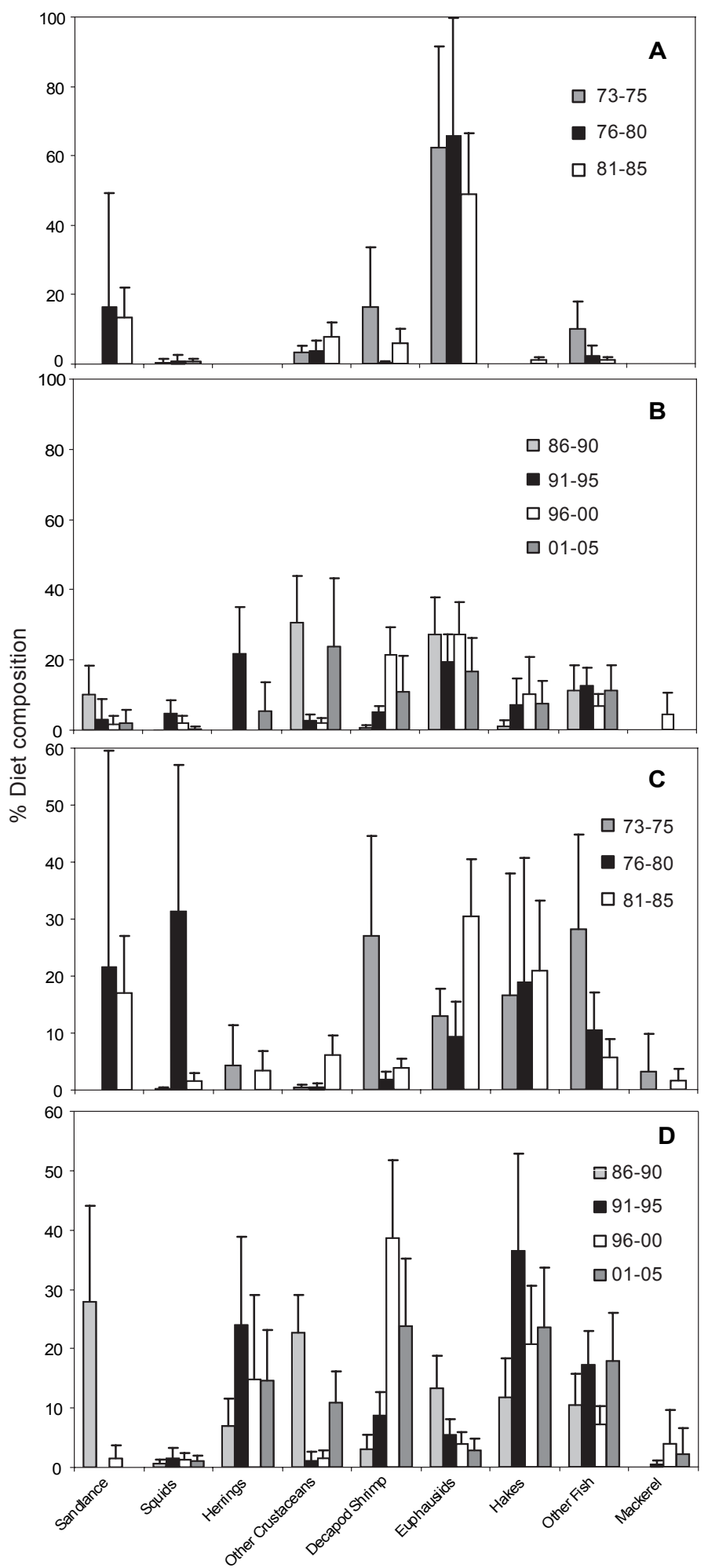

Fig. 4. The diet composition of pollock by major prey types across time blocks for (A) small size class 1973-1985, (B) small size class 1986-2005, (C) large size class 1973-1985, and (D) large size class $1986-2005$. The $95 \%$ confidence intervals are shown on the error bars. 
its highest levels, the diet of small pollock was heavily dominated by euphausiids and to a lesser extent, sandlance (Fig. 4a). At that time, the diet of large pollock was also composed of sandlance and euphausiids, but squids, hakes, and to a lesser extent, other fish were also prominent components (Fig. 4c). The other fish category includes: flatfish, sculpins, eels, and rockfish. From the late 1980 s to the mid 1990 s, the diet of small pollock was more diverse than in the prior years; other crustaceans, euphausiids, herrings, other fish, and sandlance were the most important prey categories (Fig. 4b). The diet of large pollock was dominated by sandlance, other crustaceans, hakes, other fish, euphausiids, and decapod shrimp (Fig. 4d). From the late 1990s to 2005, the prey categories that were most important in the diet of small pollock included euphausiids, other crustaceans, decapod shrimp, other fish, hakes and mackerel. For large size classes at this time, decapod shrimp and hakes were important diet components in addition to herrings, other fish and other crustaceans. Four prey types have consistently comprised a notable part of pollock diet for the three decade time series: hakes, euphausiids, decapod shrimp, and other fish. The general trend through time for both the small and large size classes has been an increasing amount of fish in the diet.

Examining specific prey further elucidates temporal shifts in diet compositions. For example, squid comprised $30 \%$ of the diet of large pollock in the early 1980 s, but prior and subsequent to this time period, squid were only a minor fraction of the diet. Similarly, sandlance composed $\sim 10-20 \%$ of large pollock's diet starting in the late 1970 s to the late 1980 s, but since that time, sandlance have been only a small component of the diet. Decapod shrimp had an opposite pattern than that of sandlance. For both large and small pollock, shrimp were impor- tant in the mid 1970s, low in the 1980s to mid 1990s and comprised major portions of the diet since the late 1990 's. From the 1970s to the late 1980s neither herring nor mackerel ever composed more than $\sim 7 \%$ of the diet of large or small pollock, but herring were prominent in the diet of both size classes in the early 1990s, and they have remained relatively important for the large size class of pollock ( $>10-15 \%$ of the diet). Mackerel were overall less prominent in the diet than herring, and their peak in diet composition for both pollock size classes was in the late 1990s.

\section{Consumption}

The average amount of food in the stomachs of large pollock varied considerably through the years, with a difference of over $80 \mathrm{~g}$ between the highest and lowest average annual values (Fig. 5). For small pollock there were only slight temporal fluctuations in stomach contents. There doesn't appear to be an inverse relationship between stomach content weight and population size. Some of the lowest values for large pollock occurred in the mid 1970s at a time when the population biomass was relatively high. However, some of the highest stomach weight values for the large size class also occurred during a time of relatively high pollock biomass. The variability in pollock stomach weights decreased in the last decade; the lower biomass in recent years may have contributed to the increased stability in the amount of food available to individual fish. From 1973-2005, the average weight of small pollock stomachs was $4.1 \mathrm{~g}$, while for large pollock it was $34.3 \mathrm{~g}$.

Annual per capita consumption for both large and small size classes of pollock fluctuated by less than one order of magnitude from 1973-2005 (Fig. 6). The minimums for the small and large size classes occurred

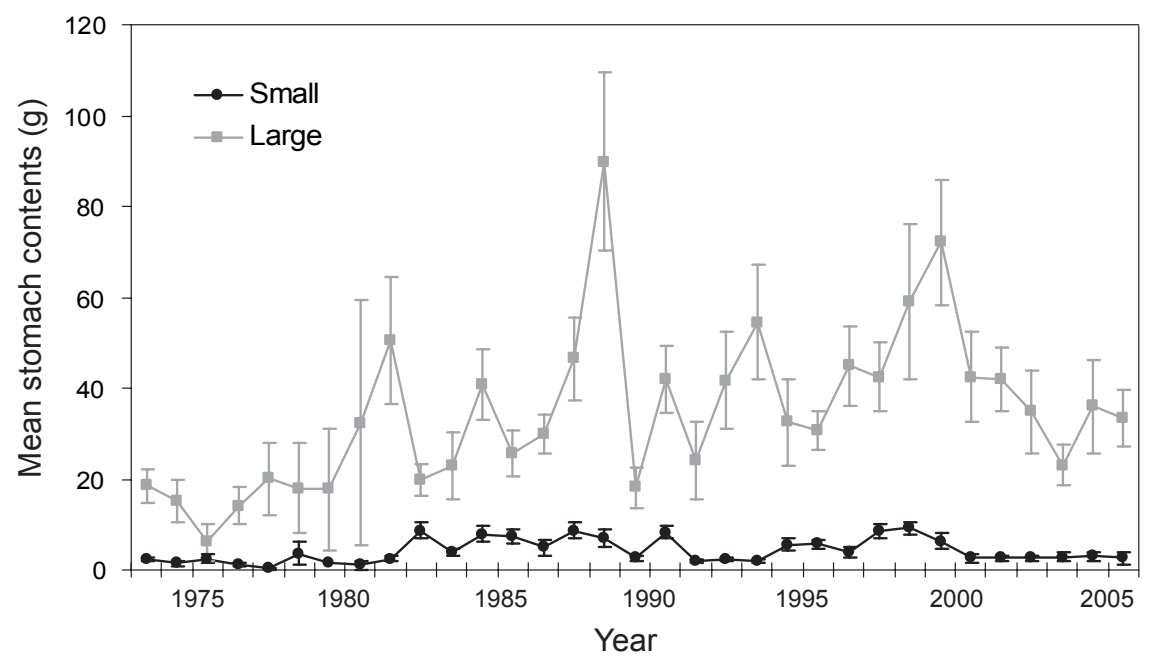

Fig. 5. Average weight and standard error of small and large pollock stomach contents. 


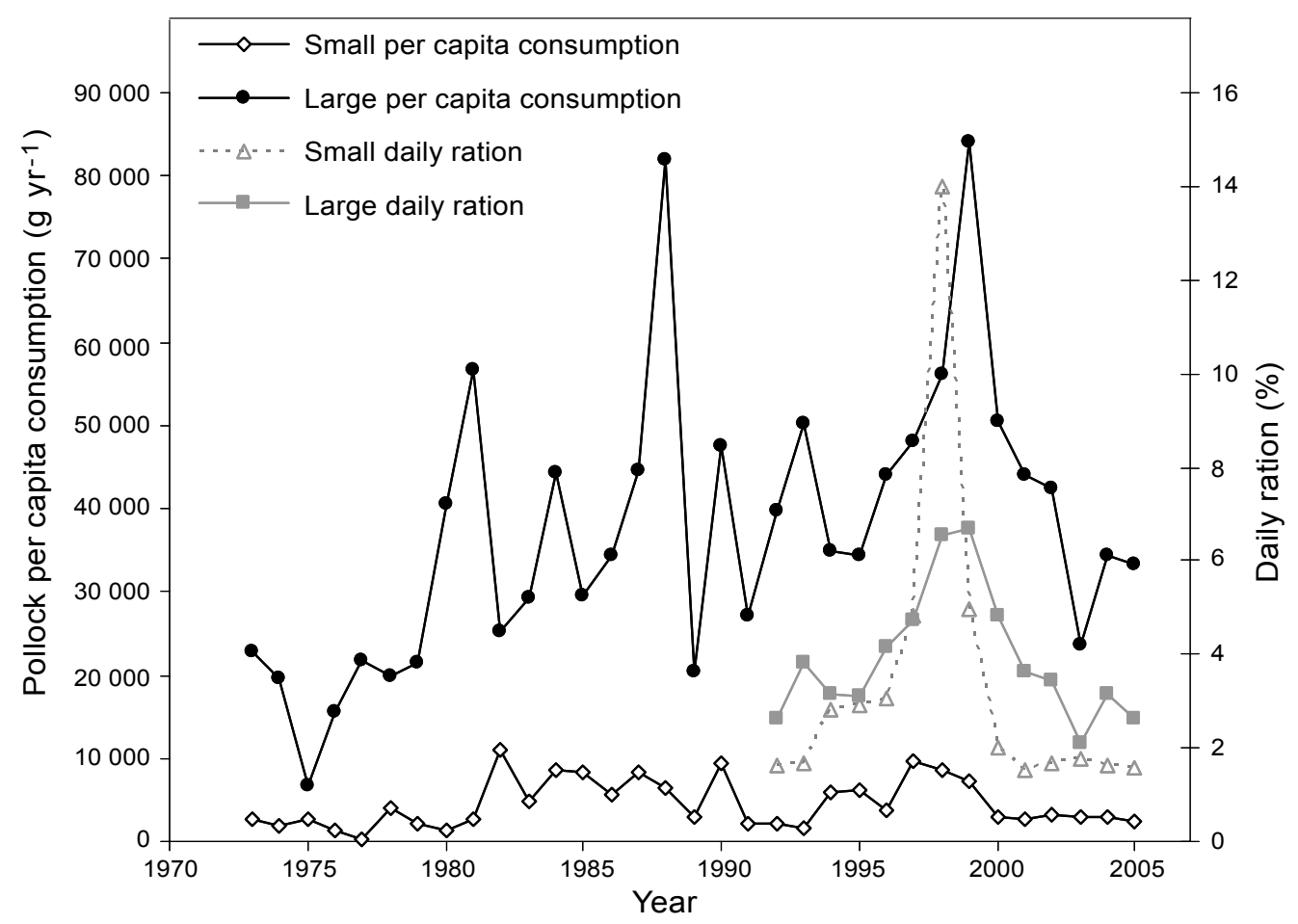

Fig. 6. Annual per capita consumption and daily ration of small and large size classes of pollock in the Northeast US continental shelf ecosystem.

in the mid 1970s, while some of the highest values for both size classes were in the mid to late 1990s when the survey index was very low. The variability in per capita consumption for small and large pollock has dampened since 2000, as pollock biomass remained at relatively low levels. Per capita consumption rates for both size classes closely followed their average stomach content weights except in the latter part of the time series when an increase in average water temperatures led to higher consumption rates. Per capita consumption for large pollock was relatively low from 1991-1995, which was when their diet was dominated by fish prey, especially hakes, herring and other fish species. The average per capita consumption rate for small pollock for the time series was $4460 \mathrm{~g} \mathrm{yr}^{-1}$ while for large pollock it was $36830 \mathrm{~g} \mathrm{yr}^{-1}$.

In general, the pattern for daily ration followed that of per capita consumption for both size classes (Fig. 6). The exception occurred in 1998 for small pollock, because the average weight of this size class was low during that time. The average daily ration for small pollock from 1992-2005 was 3.2\% while for large pollock it was $3.8 \%$.

Fig. 7 shows total pollock population level consumption for 1973-2005. The total consumption estimate varied widely from the early to late 1980 s, coincident with high interannual variability in stomach contents and population abundance (Fig. 3) during this time period. The 1980 peak in mean stomach content weights led to the maximum population consumption value in the same year. The biomass of pollock was also higher in the late 1970 s to mid 1980s relative to the rest of the time series. For the majority of the time series the fluctuations in total consumption were driven by pollock biomass trends. The exception was from the mid to late 1970s, when stomach content weights were relatively low, leading to lower total consumption. Since the early 1980s, pollock biomass and consumption trends have been relatively synchronized except for a few years in the late 1990s, when decapod shrimp comprised the biggest portion of pollock diet. The total amount of food consumed by pollock has generally increased after the mid 1990s as the population has been recovering from the historically low levels of the early 1990s.

Pollock average total annual consumption rate for the thirty-three year time series was 184152 metric tons. This value was approximately $3.4 \%$ of the annual consumption due to finfish in the Gulf of Maine and Georges Bank system (Link et al., 2006), which is similarly proportional to pollock's abundance as a fraction of total finfish biomass. Annual total system biomass flows on the 


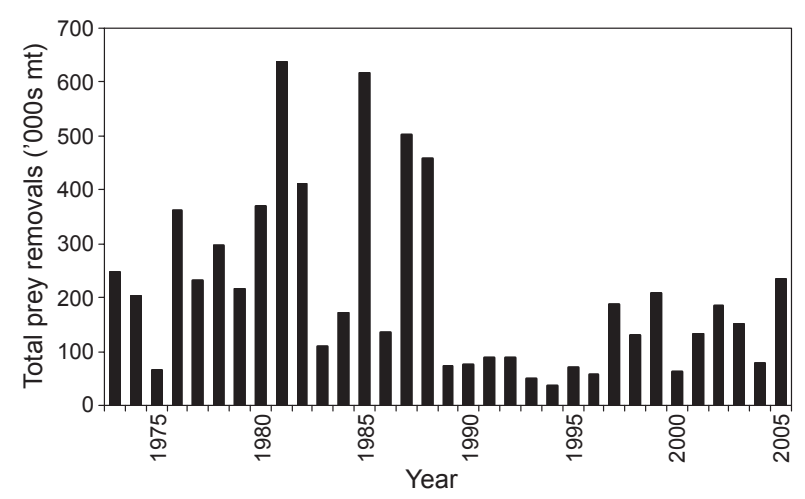

Fig. 7. Total amount of food eaten by pollock from the Northeast US continental shelf ecosystem.

US Northeast continental shelf ecosystem was estimated to be $3.9 \times 10^{9}$ metric tons (Link et al., 2006); pollock average annual consumption represents approximately $0.0047 \%$ of the total flows in the ecosystem.

\section{Prey removals}

The total biomass of the major prey groups consumed by pollock shows that early in the time series, decapod shrimp, other fish and hakes were subjected to moderate levels of predatory removals (Fig. 8). Bottom trawl survey data for northern shrimp (Pandalus borealis) indicates that biomass levels from 1973-1975 were declining from the extremely high levels of 1970-1972 (Idoine, MS 2006). As pollock abundance dramatically increased and stomach content weights increased in the late 1970 s and early 1980 s, there were concurrently very high removals of squid, sandlance and to a lesser extent, hakes and euphausiids. The bottom trawl survey indices of both Illex illecebrosus and Loligo pealeii were high during this time period (NEFSC, 2002; Hendrickson, MS 2006; Hendrickson and Jacobson, MS 2006). Sandlance abundance was very high during the late 1970s to early 1980s (Fogarty et al., 1991; Link and Garrison, 2002b). White hake (Urophycis tenuis) autumn survey biomass was at an all time high in 1980 (Sosebee, MS 2006) and both the northern and southern stocks of red hake (Urophycis chuss) also had relatively elevated biomass levels (Traver and Col, MS 2006) during the time when pollock prey removals on hake were highest. Unlike squid, sandlance and hakes, pollock predatory removals of herring have been relatively low, but consistent for the thirtythree year time series. When the survey index indicated herring biomass was very low in the late 1970s (Overholtz et al., 2004), pollock did not consume them. A similar trend occurred for pollock's removals on mackerel; as the survey biomass abundance index for mackerel fell from 1973 to the late 1970s (Overholtz, MS 2006b), pollock removals also declined.
As pollock abundance and stomach content weights fell in the late 1980s to early 1990s, sandlance and other crustaceans were eaten in moderate quantities. Pollock overall consumptive removals were very low in the early to mid 1990s, and herring and hakes were eaten at relatively low levels. From 1997-1999, pollock removals of decapod shrimp reached a relative maxima, which coincided with high biomass of northern shrimp in the autumn bottom trawl survey during this time (Idoine, MS 2006). In the late 1990s, as herring biomass recovered to levels similar to those of the 1960s (Overholtz et al., 2004), pollock predatory removals of herring also increased. The correlation between pollock removals of mackerel and the survey biomass index were similar to those of herring, albeit at lower levels, from the late 1990s to 2000s. Pollock abundance has been recovering in the last decade, but its more varied diet has resulted in consumptive removals that have been more evenly distributed across its major prey groups.

The average consumption of herring by pollock from 1973-2005 represented about $0.002 \%$ of herring's average spawning stock biomass. In 2005, the year of highest pollock removals of herring, the fraction of removal by pollock was about $0.0034 \%$ of the estimated herring spawning stock biomass. For mackerel, a smaller fraction of the spawning stock biomass was consumed by pollock, the average for the time series was $0.0002 \%$. In 1973 , the year of highest pollock removals of mackerel, pollock consumed about $0.0008 \%$ of mackerel spawning stock biomass. Pollock average consumption of squids was $15 \%$ of the combined average biomass of longfin and shortfin squid for this time period.

\section{Discussion}

The abundance and importance of pollock within commercial fisheries has changed much over time; this species is currently much less prominent in the ecosystem than two decades ago. Both the bottom trawl survey and landings data show trends of diminished biomass, which resulted in reduced consumption levels. Pollock diet has also shifted through time, and its predatory removals have affected varying groups of prey, including other commercially exploited species.

Pollock population fluctuations have been synchronous with those of the larger finfish community, but pollock oscillations are distinct from many of the other commercially exploited species. Population fluctuations for several groundfish species (e.g. Gulf of Maine cod (Gadus morhua) (Mayo and Col, 2006), Georges Bank cod (O'Brien et al., 2006), Acadian redfish (Sebastes fasciatus) (Mayo et al., 2005a), northern silver hake 

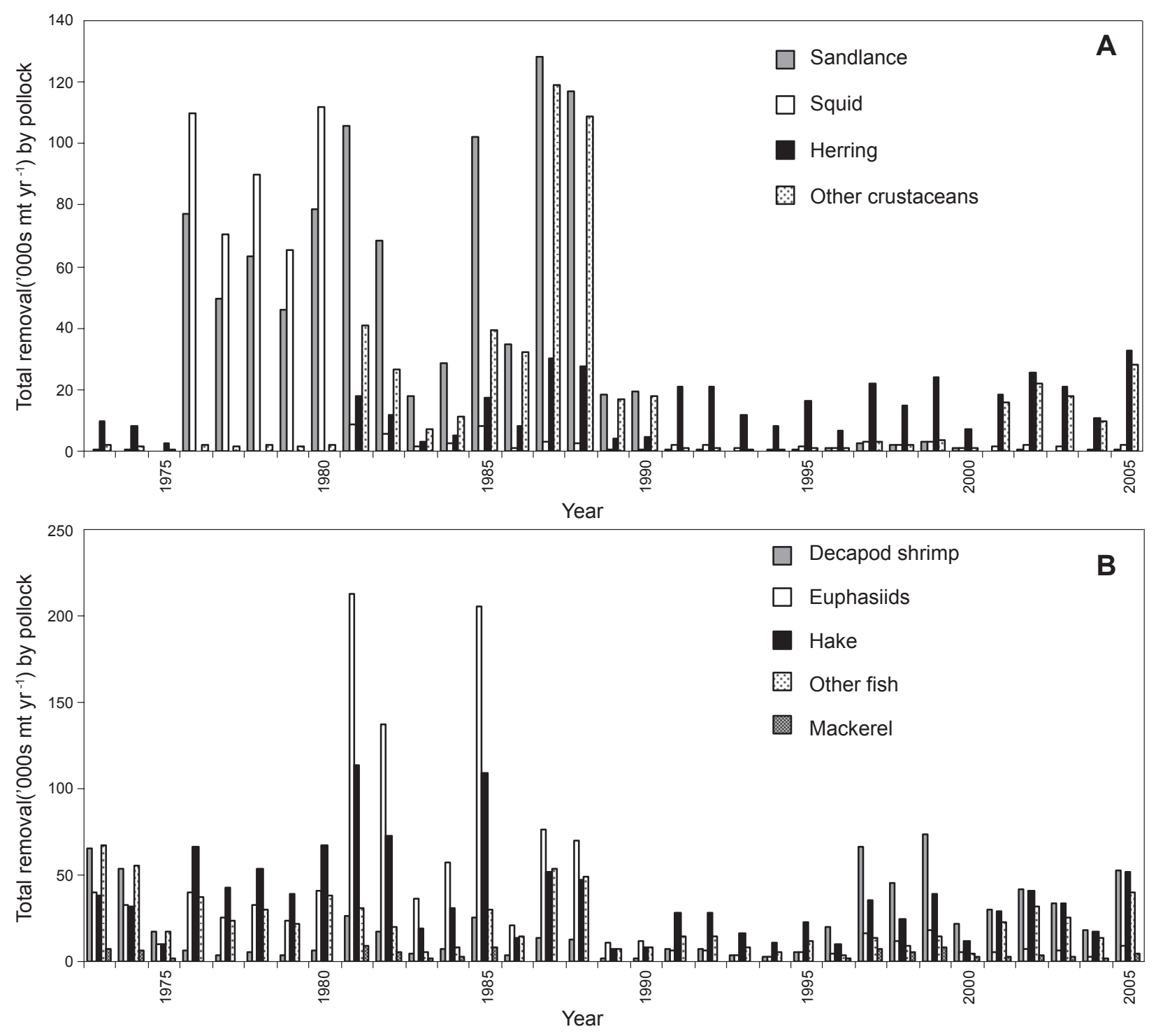

Fig. 8. Total removal by pollock of nine major prey types from the Northeast US continental shelf ecosystem in 1973-2005, for (A) sandlance, squid, herring, and other crustaceans, and (B) decapod shrimp, euphausiids, hake, other fish, and mackerel.

(Merluccius bilinearis) (NEFSC, 2006), and red hake (Urophycis chuss) (Traver and Col, MS 2006)), have been out of phase with pollock, and the peak biomasses of these species occurred several years later or earlier than peak pollock biomass. Similarly, several pleuronectiform species, including yellowtail flounder (Limanda ferruginea) (Legault, 2005), summer flounder (Paralichthys dentatus) (Terceiro, 2006) and winter flounder (Pseudopleuronectes americanus) (Hendrickson et al., MS 2006), had low biomass in the late 1970s to mid 1980 s, which is when pollock biomass was highest. Despite the fact that pollock stock size is relatively small when compared to many of these other commercially exploited species, the fact that its population dynamics are distinctive relative to other groundfish suggests that its role in influencing energy flows in the ecosystem is stronger than its relatively low biomass may imply.

Pollock is a highly active swimmer (Andersen and Riis-Vestergaard, 2004; Steinhausen et al., 2005) and consequently has high consumption rates required to fulfill those energetic demands (Du Buit, 1991). The daily ration for large pollock that was estimated in this study is similar to that in another study after converting to energetic units (Andersen and Riis-Vestergaard, 2004). Our results are slightly higher than values obtained by Durbin et al. (1983) for silver hake and Atlantic cod. Du Buit (1991) reported a similar daily ration of 2-3\% 
of body weight for pollock less than $70 \mathrm{~cm}$ in Scottish waters, which is similar to estimates for our small size class of pollock.

Pollock diet is principally composed of shrimp-like organisms, small pelagic fish and squid. The temporal fluctuations in pollock diet composition that were exhibited over the past thirty-three years reflect the relative availability of these various prey types. Previous studies in this ecosystem have characterized pollock diet as primarily being composed of pelagic species. For example, both Dexter (1969) and Langton and Bowman (1980) found that the diet of pollock was dominated by the euphausiid Meganyctiphanes norvegica and by small pelagic fishes. Similarly, studies from coastal Canadian waters (Rangely and Kramer, 1995), the Scotian Shelf (Carruthers et al., 2005), Scottish waters (Du Buit, 1991) the North Sea (Bergstad, 1991, Bromley et al., 1997), and from Icelandic waters (Jaworski and Ragnarsson, 2006), have all described pollock diet as strongly oriented toward pelagic prey, often with $>50 \%$ of pollock diet comprised of euphausiids. Conversely, Ojeda and Dearborn (1991) suggested that juvenile pollock consume more benthic organisms, but they also noted the importance of small pelagic fishes. Although our results generally confirm that pollock is predominately a pelagic feeder, long term patterns in pollock diet revealed that there have been notable shifts in the particular pelagic prey consumed. Specifically, in the past decade decapod shrimp, other crustaceans, herrings and hakes have become more important in pollock diet, reflecting increases in the relative availability of these prey types and suggestive of different sources of energy flow are being utilized in the ecosystem than in prior decades.

The prey species or groups that constitute the major components of pollock diet have been temporally variable. On the Scotian Shelf in the western Atlantic, Carruthers et al. (2005) attributed recent sharp declines of euphausiid prey in pollock diets to the diminution in abundance of these pelagic prey. Similar species, such as Atlantic cod, have also been shown to have diet compositions that shift in accordance with relative prey availability (Hanson and Chouinard, 2002; Link and Garrison, 2002b; Smith et al., 2007); thus pollock opportunistic feeding patterns in this ecosystem are not surprising.

Although the large gadids have opportunistic feeding habits, each species concentrates on a different portion of the prey field. For example, haddock primarily feed on benthic invertebrates (Garrison and Link, 2000b; Link and Almeida, 2000; Jarowski and Ragnarsson, 2006), whereas cod are more strongly piscivorous but still demersally oriented (Garrison and Link, 2000b;
Link and Garrison, 2002b). Thus the large gadid species in northeast US waters reflect a gradient of primarily benthic to pelagic feeding habits and therefore any major shifts in the direction or magnitude energy flow is likely to affect one of the major gadid species. Of the principal groundfish, pollock diet composition is most similar to Acadian redfish and red hake (Garrison and Link, 2000b; Link and Almeida, 2000).

Pollock consumption has scaled with the total energy flow among the finfish in the ecosystem. The proportion of total finfish biomass comprised by pollock is small, but very similar to its fraction of all annual consumption due to finfish. For the past thirty-three years, the total amount of prey removed by pollock principally followed fluctuations in pollock abundance and its temporally shifting diet composition largely reflected changes in the relative abundance of prey. Fishing pressure has directly and indirectly through food web interactions, strongly affected several trophic levels in the Northeast US continental shelf ecosystem over the past several decades (e.g. Fogarty and Murawski, 1998).

Significant predation by pollock on commercially valuable fish has been noted on both sides of the Atlantic. Du Buit (1991) found that pollock in the waters surrounding Scotland consumed significant quantities of Norway pout, blue whiting and haddock and speculated that short term declines in pollock populations may have partially contributed to biomass increases in North Sea Norway pout. Sparholt et al. (2002) also found that biomass declines in pollock and two other predators in the North Sea were linked to lowered mortality of Norway pout. In the northeast US, pollock consumption of commercially exploited species such as squid represents a substantial removal that, if not accounted for in natural mortality estimates, could lead to considerable underestimates of prey biomass (e.g. Overholtz and Link, 2007). Similarly, Ojeda and Dearborn (1991) suggested that the significant predation mortality by pollock and other predators on commercially valuable pelagic species such as herring and mackerel should be accounted for in the population assessments of these prey species. Over the thirty-three year time series, pollock removed four times as much herring as mackerel, likely reflecting their preference for clupeids and avoidance of mackerel (Pinnegar et al., 2003).

There has been a decade long trend of increasing biomass for pollock and some other groundfish species (e.g. Georges Bank haddock and Acadian redfish) in the Northeast US continental shelf ecosystem (Brodziak et al., 2005; Mayo et al., 2005a). Commercially exploited prey populations such as squid, shrimp, herring or mack- 
erel could decrease due to increased predation mortality from recovering groundfish stocks (e.g. Overholtz and Link, 2007). Pollock has high exploitation rates (Mayo et al., 2005b), and even a relatively small change in its fishing mortality could lead to a dramatic change in its abundance. As ecosystem-based fisheries management is increasingly recognized as a desirable goal, the effect of changing predator populations on commercially exploited prey and vice-versa will need to be acknowledged and quantified. In the case of predatory species such as pollock, maximized yield at higher trophic levels implies that catch limits for lower trophic levels may need to be adjusted to account for predatory demand.

\section{Acknowledgments}

We thank present and past members of the Food Web Dynamics Program for collecting and maintaining the data needed for this work. The content of this paper benefited from comments provided by K. Friedland, R. Pikanowski and two anonymous reviewers. This work was supported by Lenfest Ocean Program Grant Number 2004-001492-105.

\section{References}

ANDERSEN, N. G., and J. RIIS-VESTERGAARD. 2004. Alternative model structures for bioenergetics budgets of a cruising predatory gadid: incorporating estimates of food conversion and costs of locomotion. Can. J. Fish. Aquat. Sci., 61: 2413-2424. doi:10.1139/f04-153

AZAROVITZ, T. R. 1981. A brief historical review of the Woods Hole Laboratory trawl survey time series. In: Bottom trawl surveys. W. G. Doubleday and D. Rivard (eds.). Can. Spec. Publ. Fish. Aquat. Sci., 58: 62-67.

BERGSTAD, O. A. 1991. Distribution and trophic ecology of some gadoid fish of the Norwegian deep: food web linkages and comparisons of diet and distributions. Sarsia, 75: 315-325.

BRODZIAK, J., M. TRAVER, and L. COL. 2005 Georges Bank Haddock. In: Assessment of 19 Northeast groundfish stocks through 2004. 2005 Groundfish Assessment Review Meeting (2005 GARM), Northeast Fisheries Science Center, Woods Hole, Massachusetts, 15-19 August 2005. R. K. Mayo and M. Terceiro (eds.). Northeast Fish. Sci. Cent. Ref. Doc., 05-13, Section 2, p. 30-80. http:// www.nefsc.noaa.gov/nefsc/publications/crd/crd0513/ crd0513.pdf

BROMLEY, P. J., T. WATSON, and J. R. G. HISLOP. 1997. Diel feeding patterns and the development of food webs in pelagic 0-group cod (Gadus morhua L.), haddock (Melanogrammus aeglefinus L.), whiting (Merlangiusmerlangus L.), saithe (Pollachius virens L.), and Norway pout (Trisopterus esmarkii Nilsson) in the northern North Sea. ICES J. Mar. Sci., 54: 846-853. doi:10.1006/ jmsc.1996.0211

CARGNELLI, L. M., S. J. GRIESBACH, D. B. PACKER, P. L. BERRIEN, D. L. JOHNSON, and W. W. MORSE. 1999. Essential fish habitat source document: pollock, Pollachius virens, life history and habitat characteristics. NOAA Tech. Memo., NMFS-NE-131, 35 p. http://www. nefsc.noaa.gov/nefsc/publications/tm/tm131/tm131.pdf

CARRUTHERS, E. H., J. D. NIELSON, C. WATERS, and P. PERLEY. 2005. Long-term changes in the feeding of Pollachius virens on the Scotian Shelf: responses to a dynamic ecosystem. J. Fish. Biol., 66: 327-347. doi:10.1111/ j.0022-1112.2005.00594.x

DEXTER, R. W. 1969. Studies on the food habits of whiting, redfish and pollock in the Gulf of Maine. J. Mar. Biol. Ass. India, 11: 288-294.

DU BUIT, M. H. 1991. Food and feeding of saithe (Pollachius virens L.) off Scotland. Fish. Res., 12: 307-323. doi:10.1016/0165-7836(91)90015-8

DURBIN, E. G., A. G. DURBIN, R. W. LANGTON, and R. E. BOWMAN. 1983. Stomach contents of silver hake, Merluccius bilinearis, and Atlantic cod, Gadus morhua, and estimation of their daily rations. Fish. Bull., 81: 437-454.

EGGERS, D. M. 1977. Factors in interpreting data obtained by diel sampling of fish stomachs. J. Fish. Res. Board Can., 34: 290-294.

ELLIOT, J. M., and L. PERSSON. 1978. The estimation of daily rates of food consumption for fish. J. Anim. Ecol., 47: 977-999. doi:10.2307/3682

FOGARTY, M. J., E. B. COHEN, W. M. MICHAELS, and W. W. MORSE. 1991. Predation and the regulation of sand lance populations: an exploratory analysis. ICES Mar. Sci. Symp., 193: 120-124.

FOGARTY, M. J., and S. A. MURAWSKI. 1998. Large scale disturbance and the structure of marine ecosystems: fishery impacts on Georges Bank. Ecol. App., 8(1) Suppliment: S6-S22.

GARRISON, L. P., and J. S. LINK. 2000a. Fishing effects on the spatial distribution and trophic guild structure of the fish community in the Georges Bank region. ICES J. Mar. Sci., 57: 723-730. doi:10.1006/jmsc.2000.0713

2000b. Dietary guild structure of the fish community in the Northeast United States continental shelf ecosystem. Mar. Ecol. Prog. Ser., 202: 231-240. doi:10.3354/ meps 202231

GERKING, S. D. 1994. Feeding ecology of fish. Academic Press, San Diego, CA, 416 p.

HANSON, J. M., and G. A. CHOUINARD. 2002. Diet of Atlantic cod in the southern Gulf of St. Lawrence as an index of ecosystem change. J. Fish. Biol., 60: 902-922.

HENDRICKSON, L. MS 2006. Status of fishery resources off the Northeastern US-Northern Shortfin Squid. December 2006. Northeast Fisheries Science Center Resource Evaluation and Assessment Division. March 2007. http://www. nefsc.noaa.gov/sos/spsyn/iv/sfsquid/

HENDRICKSON, L., and L. JACOBSON. MS 2006. Status of fishery resources off the Northeastern US-Longfin inshore squid. December 2006. Northeast Fisheries Science Center Resource Evaluation and Assessment Division. March 2007 httn.//www.nefsc.noaa.gov/sos/spsyn/iv/lfsquid/ 
HENDRICKSON, L., P. NITSCHKE, and M. TERCEIRO. MS 2006. Status of fishery resources off the Northeastern US- Winter flounder. December 2006. Northeast Fisheries Science Center Resource Evaluation and Assessment Division. May 2007. http://www.nefsc.noaa.gov/sos/spsyn/ fldrs/winter/

HOLLOWED, A. B., J. N. IANELLI, and P. A. LIVINGSTON. 2000. Including predation mortality in stock assessments: a case study for Gulf of Alaska walleye pollock. ICES J. Mar. Sci., 57: 279-293. doi:10.1006/jmsc.1999.0637

IDOINE, J. MS 2006. Status of fishery resources off the Northeastern US-Northern shrimp. December 2006. Northeast Fisheries Science Center Resource Evaluation and Assessment Division. March 2007. http://www.nefsc.noaa. gov/sos/spsyn/iv/shrimp/

JAWORSKI, A., and S. A. RAGNARSSON. 2006. Feeding habits of demersal fish in Icelandic waters: a multivariate approach. ICES J. Mar. Sci., 63: 1682-1694. doi:10.1016/ j.icesjms.2006.07.003

LANGTON, R. W., and R. E. BOWMAN. 1980. Food of fifteen Northwest Atlantic gadiform fishes. NOAA Spec. Sci. Rept.-Fish., No. 740, 23 p.

LEGAULT, C. M. 2005. Georges Bank Yellowtail flounder. In: Assessment of 19 Northeast groundfish stocks through 2004. 2005 Groundfish Assessment Review Meeting (2005 GARM), Northeast Fisheries Science Center, Woods Hole, Massachusetts, 15-19 August 2005. R. K. Mayo and M. Terceiro (eds.). Northeast Fish. Sci. Cent. Ref. Doc., 05-13, Section 2, p. 81-102. http://www.nefsc. noaa.gov/nefsc/publications/crd/crd0513/crd0513.pdf

LINK, J. S., and F. P. ALMEIDA. 2000. An overview and history of the food web dynamics program of the Northeast Fisheries Science Center, Woods Hole, Massachusetts. NOAA Tech. Memo., NMFS-NE-159, 60 p. http://www. nefsc.noaa.gov/nefsc/publications/tm/tm159/tm159.pdf

LINK, J. S., and L. P. GARRISON. 2002a. Changes in piscivory associated with fishing induced changes to the finfish community on Georges Bank. Fish. Res., 55: 71-86. doi:10.1016/S0165-7836(01)00300-9

2002b. Trophic ecology of Atlantic cod Gadus morhua on the Northeast US continental shelf. Mar. Ecol. Prog. Ser., 227: 109-123. doi:10.3354/meps227109

LINK, J. S., L. P. GARRISON, and F. P. ALMEIDA. 2002. Ecological interactions between elasmobranchs and groundfish species on the Northeast U.S. Shelf. I: Evaluating Predation. N. Am. J. Fish. Manage., 22: 550-562.

LINK, J. S., C. A. GRISWOLD, E. M. METHRATTA, and J. GUNNARD. (eds). 2006. Documentation for the energy modeling and analysis eXercise (EMAX). Northeast Fish. Sci. Cent. Ref. Doc, 06-15, 166 p. http://www.nefsc.noaa. gov/nefsc/publications/crd/crd0615/crd0615.pdf

MARAK, R. R. 1960. Food habits of larval cod, haddock and coalfish in the Gulf of Maine and Georges Bank area. J. Cons. Int. Explor. Mer, 25: 147-157.

MAYO, R. K., J. BRODZIAK, M. TRAVER, and L. COL. 2005a. Gulf of Maine/Georges Bank Acadian Redfish. In: Assessment of 19 Northeast groundfish stocks through 2004. 2005 Groundfish Assessment Review Meeting (2005 GARM), Northeast Fisheries Science Center,
Woods Hole, Massachusetts, 15-19 August 2005. R. K. Mayo and M. Terceiro (eds.). Northeast Fish. Sci. Cent. Ref. Doc., 05-13, Section 2, p. 372-388. http://www.nefsc.noaa.gov/nefsc/publications/crd/crd0513/crd0513.pdf

MAYO, R. K., and L. A. COL. 2006. The 2005 assessment of the Gulf of Maine Atlantic cod stock. Northeast Fish. Sci. Cent. Ref. Doc., 06-02, 109 p. http://www.nefsc.noaa. gov/nefsc/publications/crd/crd0602/crd0602.pdf

MAYO, R. K., L. COL, and M. TRAVER. 2005b Georges Bank/Gulf of Maine Pollock. In: Assessment of 19 Northeast groundfish stocks through 2004. 2005 Groundfish Assessment Review Meeting (2005 GARM), Northeast Fisheries Science Center, Woods Hole, Massachusetts, 15-19 August 2005. R. K. Mayo and M. Terceiro (eds.). Northeast Fish. Sci. Cent. Ref. Doc., 05-13, Section 2, p. 359-371. http://www.nefsc.noaa.gov/nefsc/publications/ crd/crd0513/crd0513.pdf

MAYO, R. K., J. M. MCGLADE, and S. H. CLARK, 1989. Patterns of exploitation and biological status of pollock, Pollachius virens L., in the Scotian Shelf, Gulf of Maine, and Georges Bank area. J. Northw. Atl. Fish. Sci., 9: 1336.

MOUNTAIN, D. G., M. H. TAYLOR, and C. BASCUÑÁN. 2004. Revised procedures for calculating regional average water properties for Northeast Fisheries Science Center cruises. Northeast Fish. Sci. Cent. Ref. Doc., 04- 08; 53 p. http://www.nefsc.noaa.gov/nefsc/publications/crd/ crd0408/crd0408.pdf

NEFC. 1988. An evaluation of the bottom trawl survey program of the Northeast Fisheries Center. NOAA Tech. Memo., NMFS-F/NEC-52, 83 p. NTIS Access. No. PB88201983/AS.

NEFSC. 2002. 34th Northeast Regional Stock Assessment Workshop (34th SAW): Stock Assessment Review Committee (SARC) consensus summary of assessments. Northeast Fish. Sci. Cent. Ref. Doc., 02-06, 358 p. http:// www.nefsc.noaa.gov/nefsc/publications/crd/crd0206/ crd0206.pdf

2006. 42nd Northeast Regional Stock Assessment Workshop (42nd SAW) stock assessment report. Part A: silver hake, Atlantic mackerel, and northern shortfin squid (CRD06-09a). Northeast Fish. Sci. Cent. Ref. Doc., 06-09a, 284 p. http://www.nefsc.noaa.gov/nefsc/publications/crd/ crd0609/crd0609.pdf

2007. 44th Northeast Regional Stock Assessment Workshop (44th SAW): 44th SAW Assessment Report. Northeast Fish. Sci Center Ref. Doc., 07-10, 661 p. http:// www.nefsc.noaa.gov/nefsc/publications/crd/crd0710/ crd0710.pdf

OJEDA, F. P., and J. H. DEARBORN. 1991. Feeding ecology of benthic mobile predators: experimental analyses of their influence in the rocky subtidal communities of the Gulf of Maine. J. Exp. Mar. Biol. Ecol., 149: 13-44. doi:10.1016/0022-0981(91)90114-C

O'BRIEN, L., N. MUNROE, and L. A. COL. 2006. Assessment of the Georges Bank Atlantic cod stock for 2005. Northeast Fish. Sci. Cent. Ref. Doc., 06-10, 148 p. http:// www.nefsc.noaa.gov/nefsc/publications/crd/crd0610/ crd0610.pdf 
OVERHOLTZ, W. J. MS 2006a. Status of fishery resources off the Northeastern US-Atlantic herring. December 2006. Northeast Fisheries Science Center Resource Evaluation and Assessment Division. March 2007. http://www.nefsc. noaa.gov/sos/spsyn/pp/herring/

MS 2006b. Status of fishery resources off the Northeastern US-Atlantic mackerel. December 2006. Northeast Fisheries Science Center Resource Evaluation and Assessment Division. March 2007. http://www.nefsc.noaa. gov/sos/spsyn/pp/mackerel/

OVERHOLTZ, W. J., L. D. JACOBSON, and J. S. LINK. 2008. An ecosystem approach for assessment advice and biological reference points for the Gulf of Maine-Georges Bank herring complex. N. Amer. J. Fish. Mgmt., In press.

OVERHOLTZ, W. J., L. D. JACOBSON, G. D. MELVIN, M. CIERI, M. POWER, D. LIBBY, and K. CLARK. 2004. Stock assessment of the Gulf of Maine - Georges Bank Atlantic herring complex, 2003. Northeast Fish. Sci. Cent. Ref. Doc., 04-06, 290 p. http://www.nefsc.noaa.gov/nefsc/ publications/crd/crd0406/crd0406.pdf

OVERHOLTZ, W. J., and J. S. LINK. 2007. Consumption impacts by marine mammals, fish, and seabirds on the Gulf of Maine-Georges Bank Atlantic herring (Clupea harengus) complex during 1977-2002. ICES J. Mar. Sci., 64: 83-96.

OVERHOLTZ, W., J. S. LINK, and L. E. SUSLOWICZ. 1999. Consumption and harvest of pelagic fishes and squids in the Gulf of Maine-Georges Bank ecosystem. Proceedings of the 16th Lowell Wakefield Fisheries Symposium - Ecosystem Considerations in Fisheries Management., AK-SG-99-01, p. 163-186.

2000. Consumption of important pelagic fish and squid by predatory fish in the Northeastern USA shelf ecosystem with some fishery comparisons. ICES J. Mar. Sci., 57: 1147-1159. doi:10.1006/jmsc.2000.0802

PINNEGAR, J. K., V. M. KRENKEl, A. N. TIDD, W. A. DAWSON, and M. H. DU BUIT. 2003. Does diet in Celtic Sea fishes reflect prey availability? J. Fish. Biol., 63 (Supplement A): 197-212. doi:10.1111/j.1095-8649.2003.00204.x

RANGELY, R. W., and D. L. KRAMER. 1995. Use of rocky intertidal habiats by juvenile pollock Pollachius virens. Mar. Ecol. Prog. Ser., 126: 9-17. doi:10.3354/meps126009

SMITH, B. E., T. J. LIGENZA, F. P. ALMEIDA, and J. S. LINK. 2007. The trophic ecology of Atlantic cod: insights from tri-monthly, localized scales of sampling. J. Fish. Biol., 71: 749-762. doi:10.1111/j.1095-8649.2007.01540.x

SOSBEE, K. MS 2006. Status of fishery resources off the Northeastern US - White Hake. December 2006. Northeast Fisheries Science Center Resource Evaluation and Assessment Division. May 2007. http://www.nefsc.noaa. gov/sos/spsyn/og/hake/

SPARHOLT, H., L. I. LARSEN, and J. R. NIELSEN. 2002. Verification of multispecies interactions in the North Sea by trawl survey data on Norway pout (Trisopterus esmarkii). ICES J. Mar. Sci., 59:1270-1275. doi:10.1006/ jmsc. 2002.1296

STEINHAUSEN, F. M., J. F. STEFFENSEN, and N. G. ANDERSEN. 2005. Tail beat frequency as a predictor of swimming speed and oxygen consumption of saithe (Pollachius virens) and whiting (Merlangius merlangus) during forced swimming. Mar. Biol., 148: 197-204. doi:10.1007/s00227-005-0055-9

TERCEIRO, M. 2006. Stock assessment of summer flounder for 2006. Northeast Fish. Sci. Cent. Ref. Doc., 06-17, 119 p. http://www.nefsc.noaa.gov/nefsc/publications/crd/ crd0617/crd0617.pdf

TRAVER, M., and L. COL. MS 2006. Status of fishery resources off the Northeastern US - Red Hake. December 2006. Northeast Fisheries Science Center Resource Evaluation and Assessment Division. May 2007. http://www. nefsc.noaa.gov/sos/spsyn/pg/redhake/

TSOU, T. S. and J. S. COLLIE. 2001a. Predation-mediated recruitment in the Georges Bank fish community. ICES J. Mar. Sci., 58: 994-1001. doi:10.1006/jmsc.2001.1088

2001b. Estimating predation mortality in the Georges Bank fish community. Can. J. Fish. Aquat. Sci., 58: 908-922. doi:10.1139/cjfas-58-5-908 